\title{
Organisaation kehittämismallien juurista tulevaisuuden haasteisiin
}

\author{
Henry Honkanen
}

\author{
Organisaatioiden rakenteet ja johtamismallit ovat \\ nopeasti muuttumassa. Tämä haastaa myös \\ organisaatiokonsultoinnin ja kehittämisen parissa \\ työskenteleviä kehittämään omaa osaamistaan ja \\ toimintamallejaan. Seuraavassa luodaan katsaus \\ organisaatiokonsultoinnin historiallisiin \\ lähtökohtiin ja analysoidaan nykypäivän \\ haasteita.
}

KUVA 1. Kehittämistoiminnan tavoitteet ja arvopäämäärät

\footnotetext{
Organisaation, työtoiminnan ja henkilöstön kehittäminen on toimintaa, jonka tavoitteena on luoda edellytyksiä tai parantaa

1 organisaation suorituskykyä ja tehokkuutta (TUOTTAVUUSTAVOITE),

1 henkilöstön hyvinvointia, motivaatiota ja kasvua työssä (HYvinVOINTITAVOITE),

1 organisaation uudistumis- ja oppimiskykyä, innovatiivisuutta, muutosvalmiutta (UUDISTUMISTAVOITE),

1 organisaation ja henkilöstön kykyä toimia moniulotteisessa ympäristössä ja kykyä ymmärtää ja arvioida oman toiminnan tavoitteita, arvopäämääriä ja seurauksia (YMMÄRTÄMISTAVOITE).
}

Organisaation ja työyhteisön kehittämistoiminnan historiassa on löydettävissä kaksi vahvaa arvopäämäärää ja näihin pohjautuvaa trendiä (Honkanen 1989, Vartiainen 1994). Ensinnäkin organisaatiot on haluttu toimivan tehokkaammin ja tuottavammin. Tätä linjaa ovat edustaneet $\mathrm{mm}$.
Taylorin tieteellinen liikkeenhoito (1910-luku), rationalisoinnin perinne, työn liikeaikajärjestelmät ja 1990-luvulla näkyvimmin prosessijohtaminen ("business process improvement").

Toista linjaa on edustanut työn humanisoinnin 
perinne. Tässä organisaatioiden kehittämisen lähtökohdaksi on otettu työntekijöiden hyvinvoinnin, motivaation kehittäminen, voimavarojen vapauttaminen tai osaamisen kehittäminen. Tätä ovat edustaneet mm. ihmissuhdekoulukunta (1920luku), Lewinin toimintatutkimus, OD-malli (70luku), työpaikkademokratiakokeilut (Emery \& Thorsrud) tai Gustavsenin demokraattinen dialogi. Tämän linjan tyypillisiä heijastumia 90-luvulla ovat olleet Suomessa Engeströmin kehittävän työtutkimuksen malli, ryhmämäisten interventiomenetelmien uusi tuleminen (esim. sosiodraama ja roolitekniikat), NLP-tyyppisten menetelmien suosio tai arvojohtaminen.

$\mathrm{N}$ äiden kahden suuntauksen - tuottavuus vs. hyvinvointi - välillä nähtiin vielä 70-luvulla vallitsevan sovittamattoman ristiriidan (Honkanen 1989). Jalansijaa saivat kuitenkin yhä suuremmassa määrin sellaiset kehittämismallit, joissa tekninen ja ihmisjärjestelmä samoin kuin tehokkuus- ja hyvinvointiajattelu yhdistettiin. Tällaisia ovat olleet mm. sosiotekninen koulukunta, moderni ergonomia tai ylipäänsä systeemisen ajattelutavan yleistyminen. 80-luvulla pohdittiin paljon organisaatioiden muutoksen hallintaan, muutoskykyyn ja innovatiivisuuteen liittyviä tekijöitä. Voi sanoa, että uudistumis- ja muutoskyvystä, joustavuudesta ja innovatiivisuudesta tuli tuolloin uusi organisaation kehittämisen arvopäämäärä tuottavuuden ja hyvinvoinnin rinnalle. Oppivan organisaation käsitteeseen liittyvät kehittämismallit ovat 90-luvun ilmaus tästä.

$\mathrm{E}$ hkä tärkein muutos tapahtui johtamisajatelun puolella, mikä kiteytyi ns. HRM-mallin tai resurssijohtamisajattelun lanseeramisen muodossa 80/90-lukujen vaihteessa (Honkanen 1993). 2000-luvulle tultaessa näiden eri suuntausten edelleen jalostuminen nähdään parhaiten ehkä kompetenssiajattelussa, jossa pyritään tarkastelemaan rinnakkain manageriaalisia, behavioraalisia ja organisatorisia kyvykkyyksiä (Sparrow 1997).

Organisaatioajattelun painopistesiirtymän voi nähdä esimerkiksi seuraavasti. Perinteisessä johtamisajattelussa ensin tutkitaan markkinat, sitten rakennetaan tehdas ja hankitaan sinne koneet ja vii-

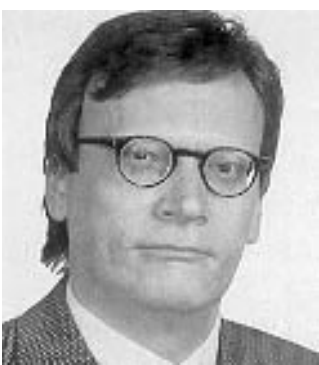

Henry Honkanen

meiseksi mietitään, minkälaisia henkilöstöresursseja tuon tehtaan pyörittäminen vaatii: tässä ihmisjärjestelmä pakotetaan jälkikäteen tiettyyn ennalta määriteltyyn rakenteeseen tai teknologiaan. 2000-luvun johtamisajattelussa voidaan itse asiassa tehdä päinvastoin: ensin hankitaan ihmiset tai osaaminen ja vasta sitten rakennetaan teknologia ja luodaan tai keksitään markkinat.

$\mathrm{O}$ lennaista tässä on ymmärtää, että nykyaikaisia organisaatioita kehitettäessä on samanaikaisesti tai rinnakkain otettava huomioon ainakin seuraavat tekijät:

- organisaation (liike)toimintaympäristö ja (liike)toiminnan ohjausjärjestelmät

- organisaation rakennetekijät, teknologinen järjestelmä, työ- ja toimintaprosessit

- organisaation sosiaalinen vuorovaikutus- tai kulttuurijärjestelmä

- organisaatiossa toimivien ihmisten yksilölliset ominaisuudet, tarpeet ja osaaminen.

Kilpailukyky rakennetaan näiden elementtien onnistuneella yhteensovittamisella. Valmista reseptiä ei ole olemassa, vaan kunkin organisaation on kussakin tilanteessa löydettävä toimiva sekoitussuhde. Tämä on suuri haaste niin johtajille kuin organisaation kehittäjille ja muutosagenteille. On osattava paljon enemmän kuin ennen, tehtävä se paremmin ja omaksuttava myös uusia asenteita, tapoja ja rooleja tehdä työtä. Heiltä vaaditaan ennen kaikkea roolijoustavuutta ja poikkiammatillista orientaatiota.

Tämä on usein tehtävä nopeasti muuttuvassa, jopa kaoottisessa ympäristössä, jossa on välillä vaikea ymmärtää ilmiöitä ja navigoida. Niinpä organisaatiossa on huolehdittava myös henkilöstön kyvystä toimia moniulotteisessa ympäristössä ja ky- 
vystä ymmärtää ja arvioida oman toiminnan tavoitteita, arvopäämääriä ja seurauksia. Tämä voidaan nähdä yhtenä neljästä organisaation kehittämistoiminnan tavoitteista. Se poikkeaa kolmesta muusta arvomäärästä siinä mielessä, että siihen liittyvä tiedon intressi on hermeneuttinen eli tarve ymmärtää tai tulkita maailmaa.

Tämä ymmärtämistavoite ei mitenkään silmiinpistävästi korostu organisaatioiden kehittämishankkeiden tavoitteiden kärkipäässä, vaikka sen merkitys onkin yhä paremmin tiedostettu. Ymmärtämistavoite toteutuukin usein koulutus- ja kehittämishankkeiden sivutuotteena tarjoamalla ihmisille ajatteluvälineitä jäsentää ilmiöitä. Myös päivittäisjohtamisen yksi tärkeimmistä tehtävistä on tarjota organisaatiossa toimiville välineet, viitekehys tai malli, jonka avulla todellisuutta voidaan tulkita ja asioille annetaan merkitys. Esimerkiksi Scheinin (1987a) mukaan johtajien ainoa todella tärkeä tehtävä on luoda ja johtaa kulttuuria eli organisaation merkitys- ja tulkintamalleja.

\section{ORGANISAATION JOHTAMINEN JA SEN KONSULTOINTI}

Johtajan, konsultin tai muutosagentin tärkeimpiä tehtäviä tai rooleja on siis toimia eräänlaisina symbolitulkkeina. Konsultointi- ja johtamistyön mallien lähestymistä on ennakoinut mm. Mintzberg (1983). Mintzbergin organisaatiomallissa kehittyneimmän organisaatiomuodon "adhokratian" ytimen muodostavat eräänlaiset konsulttityyppiset koordinaattorit tai agentit, jotka pyrkivät pitämään hajanaisen ja ameebamaisen organisaation kasassa. Tässä siis johtaminen muuttuu hyvin konsulttimaiseksi toiminnaksi. Ero konsultti-muutosagentin ja linjajohtajan välillä hämärtyy. Niinpä Schein (1987b) tarjoilee perinteiseen OD-perinteeseen liittyvää prosessikonsultoinnin malliaan myös johtamisen välineeksi.

$\mathrm{K}$ onsultoinnin ja johtamisen välinen yhteys pitäisi itse asiassa olla itsestäänselvyys. Konsultointihan on asiantuntijapalvelua, jonka tarkoitus on tukea organisaation johtoa työssään tai täs-

KUVA 2. Johtamisen ja kehittämisen tehtävät organisaatiossa

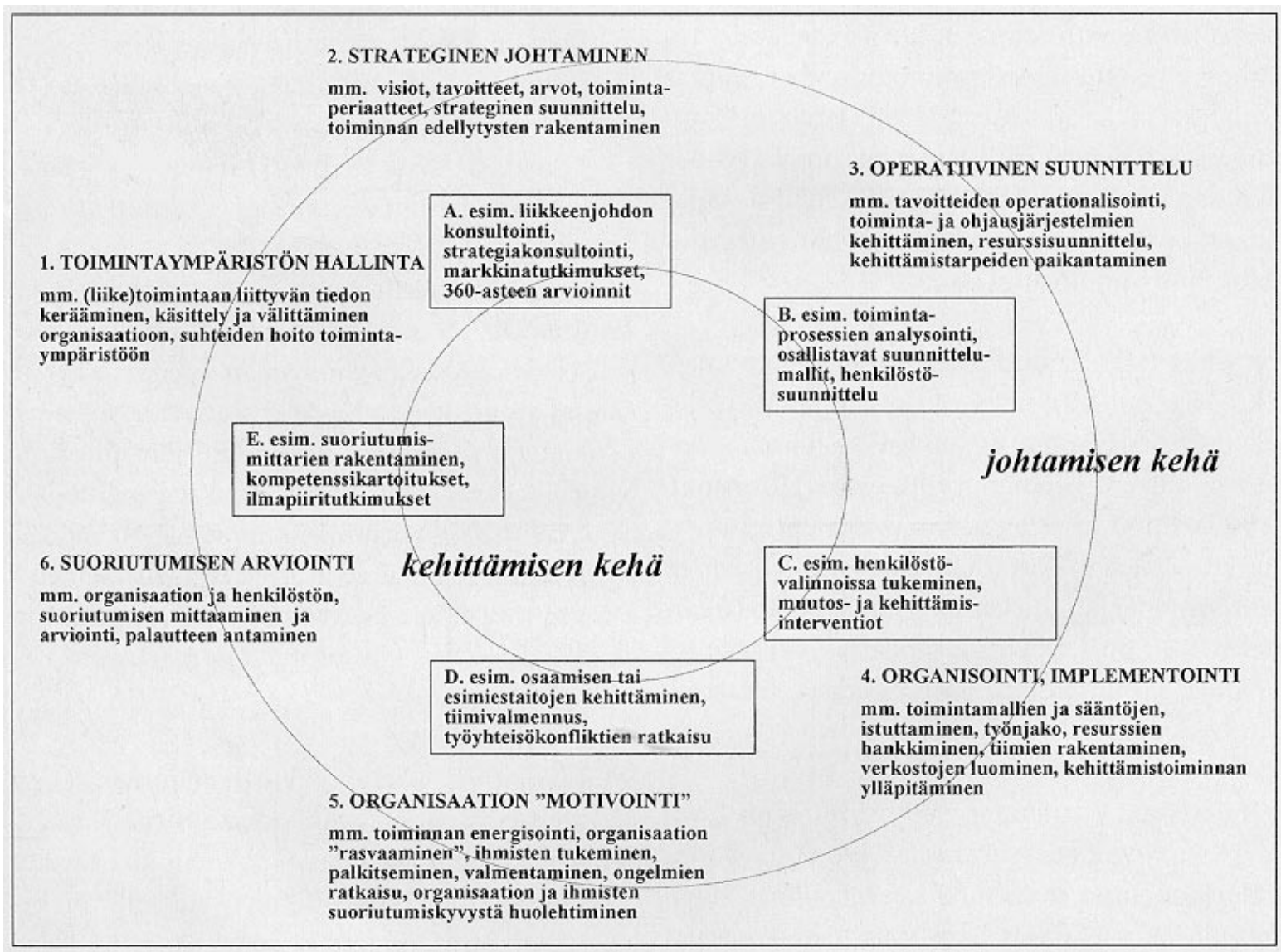


mällisemmin: tukea eri johtamisfunktioiden toteutumista organisaatiossa. Organisaation kehittämistoiminnan tavoitteet ja varsinainen sisältö nousevatkin organisaation johtamisen perustehtävistä tai funktioista. Toisaalla johtamistyön tai tehtävien (Yukl 1994) ja toisaalla konsultoinnin eri alueiden ja menetelmien (French \& Bell 1990) kuvausjärjestelmiä ja typologioita on kirjallisuudessa tarjolla runsaastikin. Alla esitetyssä johtamisen ja kehittämisen kehämallissa johtamista on kuvattu eräänlaisena ongelmanratkaisuprosessina (kuva 2).

$\mathrm{O}$ rganisaatioiden monimutkaistuessa johtamistyönkin alueelle on rakennettu työnjakoa. Eri johtamistehtäviin on erikoistunut juuri siihen erikoistunut johtaja- tai esimieskunta. Kyse ei ole vain organisaation hierarkiaan liittyvästä työnjaosta (esimerkiksi strateginen johto, operatiivinen johto, työnjohto), vaan johtajuutta on hajautunut myös erikoisfunktioihin (esimerkiksi tuotanto, myynti, talous, henkilöstö). Tämä on näkynyt myös vastaavien johtamistyössä käytettävien konsultointipalveluiden eriytymisenä. Johtamisen kehältä on löydettävissä vastaava konsultointimuotokin (kuva 2).

Organisaatiokonsultoinnin ja -kehittämisen ammatillinen kenttä onkin varsin kirjava (kuva 3). Itse asiassa kun puhutaan organisaatiokonsultoinnista, on aina ensin kysyttävä, mitä, miten ja missä roolissa konsultoi.

KUVA 3. Organisaatiokonsultoinnin tyypit

\begin{tabular}{|c|c|c|}
\hline $\begin{array}{l}\text { kehittämisen, konsul- } \\
\text { toinnin kohde }\end{array}$ & $\begin{array}{l}\text { mihin tai miten tarkemmin } \\
\text { halutaan vaikuttaa }\end{array}$ & $\begin{array}{l}\text { konsultti- tai asiantuntija- } \\
\text { tyyppi }\end{array}$ \\
\hline $\begin{array}{l}\text { RAKENTEETJA TOIMINTA- } \\
\text { JÄRJESTELMÄT }\end{array}$ & $\begin{array}{l}\text { (liike)toiminta, työnjako, } \\
\text { toimintaprosessit ja -järjes- } \\
\text { telmät, organisaation raken- } \\
\text { ne }\end{array}$ & $\begin{array}{l}\text { - liikkeenjohdon konsultit-lii- } \\
\text { ketoiminnan kehittämispäälli- } \\
\text { köt-tuotanto/ohjausjärjestelmi- } \\
\text { en kehittäjät, atk-konsultit }\end{array}$ \\
\hline TYÖTOIMINTA & $\begin{array}{l}\text { työtoiminnan, työympäris- } \\
\text { tön, terveyden ja turvallisuu- } \\
\text { den kehittäminen }\end{array}$ & $\begin{array}{l}\text {-työntutkijat, -kehittäjät } \\
\text {-työpsykologian asiantuntijat } \\
\text {-ergonomit }\end{array}$ \\
\hline HENKILÖSTÖRESURSSIT & $\begin{array}{l}\text { resurssien allokointi, henki- } \\
\text { lövalinnat, urajohtaminen, } \\
\text { resurssikartoitukset, ulosohja- } \\
\text { us, } \\
\text { osaamisen kehittäminen, } \\
\text { koulutus, esimiestaidot jne. }\end{array}$ & $\begin{array}{l}\text {-rekrytointi- ja henkilöarvioin- } \\
\text { tikonsultit } \\
\text {-henkilöstöpäälliköt ja -suun- } \\
\text { nittelijat } \\
\text {-koulutusinstituutiot, koulutta- } \\
\text { jat, koulutuskonsultit } \\
\text {-koulutuspäälliköt ja -suunnit- } \\
\text { telijat }\end{array}$ \\
\hline $\begin{array}{l}\text { KULTTUURI,ARVOTJA } \\
\text { JOHTAMINEN }\end{array}$ & $\begin{array}{l}\text { yksilön hyvinvointi, ihmisten } \\
\text { välisen vuorovaikutuksen ke- } \\
\text { hittäminen, konfliktien ratkai- } \\
\text { su, ongelmanratkaisu- } \\
\text { taidot }\end{array}$ & $\begin{array}{l}\text {-työnohjaajat, ryhmädynamiikan } \\
\text { kouluttajat } \\
\text {-perinteiset OD-konsultit ja } \\
\text { muutosagentit }\end{array}$ \\
\hline $\begin{array}{l}\text { MUUTOS } \\
\text { ORGANISAATIOSSA }\end{array}$ & $\begin{array}{l}\text { muutosprosessit, osallistuva } \\
\text { muutostoiminta, oppiva or- } \\
\text { ganisaatio, tiimien kehittämi- } \\
\text { nen }\end{array}$ & $\begin{array}{l}\text {-organisaatioteorian ja -psy- } \\
\text { kologian asiantuntijat }\end{array}$ \\
\hline
\end{tabular}


$\mathrm{M}$ onessa organisaatiossa erillään toimineet henkilöstö- ja koulutusosastot ovat hyvä esimerkki äärimmäisyyksiin menneestä työnjaosta. Tällaisissa organisaatioissa on saatettu tehdä henkilöstö- ja koulutussuunnittelua yrittämättäkään koordinoida niitä toisiinsa. Organisaatioiden sisällä henkilöstö- ja koulutustoimintoja on yhdistetty 90-luvulla, mutta konsultointipuolella tällainen integroituminen on sen sijaan ollut hidasta. Esimerkiksi rekrytointi- ja henkilöarviointikonsulttien palvelumallit ovat säilyneet lähes muuttumattomina, vaikka kompetenssiajattelu suorastaan haastaa ja tarjoaa mahdollisuuden sovittaa henkilöstön kehittämis- ja valintamenettelyjä toisiinsa.

HRM- ajattelussa tai prosessijohtamismallissa tavoitteena on purkaa johtamisen lokeroitumista ja integroida tehokkaammin johtajuuden keskeisimpiä funktioita toisiinsa. Tämä haastaa vastaavasti konsultointityötä tekevät laajentamaan käsitystään konsultoinnista. Kyse ei ole vain sisällöllisestä laajentamisesta ja poikki- tai moniammatillisen toimintamallin omaksumisesta. Myös konsultointityön toimintamalleja ja -rooleja on uudelleenarvioitava. Kuvassa 4 on eritelty organisaatiokonsultoinnin eri toiminta- ja roolimalleja. Vastaavasti Schein (1988) jakaa konsultoinnin kolmeen tyyppiin: asiantuntijamalliin, lääkäri-potilas-malliin ja prosessikonsultointiin.

Esimerkiksi siirtyminen asiantuntijaroolista avittajan rooliin on suurempi harppaus, kuin mitä usein ymmärretään. Näissä kahdessa roolissa toimiminen edellyttää aivan erilaista toimintaotetta, ammatillista asennetta, osaamista ja työmenetelmiä. Hyvä asiantuntija voi pilata uskottavuutensa yrittäessään toimia avittajan tai valmentajan roolissa. Vastaavasti prosessikonsultti menettää mahdollisuutensa toimia avittajan roolissa, jos hän intoutuu liiaksi esiintymään asiantuntijana tai opettajana (Järvinen 1997). Organisaatiokonsultoinnissa on kuitenkin selvä paine omaksua yhä suuremmassa määrin avittajamaista roolia. Suuntaus on paralleeli johtamistyön muutospaineille, jossa esimiehiltä odotetaan valmentajan roolia.

\section{ORGANISAATIOKONSULTOIN- NIN KÄYTTÖTEORIA JA KON- SULTTIVALMENNUS}

Organisaatiokonsultteina ja -kehittäjinä toimitaan hyvin erilaisista

1) arvolähtökohdista ja tavoitteista,

2) ammatillisesta taustasta,

3 ) suhteista ja kontakteista organisaation johtamisfunktioihin,

4 ) konsultointityön malleista ja rooleista käsin.

Nämä erilaiset lähtökohdat vaikuttavat myös siihen käyttöteoriaan, jota kukin konsultti ja kehittäjä soveltaa omassa työssään, kantaa mukanaan organisaation ja pyrkii välittämään muille. Yleensä käyttöteoriat ovat pikemminkin implisiittisiä kuin kokonaan "tietoisia" rakennelmia. Organi-

KUVA 4. Konsultin, muutosagentin eri rooleja

ASIANTUNTIJA

neuvonantaja, ekspertti, tekninen spesialisti

KOULUTTAJA,OPETTAJA

ANALYSOIJA

tutkija, ongelmanratkaisussa avustaminen, siinä mukana oleminen

AVITTAJA, VALMENTAJA

prosessikonsultti, peilinä toimiminen konsultilla hallussa oikea tieto tai taito; konsultti kertoo oikeat ratkaisumallit asiakkaalle $\rightarrow$ konsultin hallussa oikea tieto tai taito, joka siirretään asiakkaalle, jotta tämä itse kykenisi käyttämään sitä

$\rightarrow$ konsultti kerää asiakkaan puolesta tietoa ja analysoi sitä; auttaa asiakasta hahmottamaan ongelmaa ja tuomaan siihen näkökulmia $\rightarrow$ konsultti luo puitteet, jotta asiakas itse kykenisi erittelemään ongelmaa ja löytämään siihen ratkaisumalleja 
KUVA 5. Organisaatiokonsultin käyttöteorian rakennuspalikat

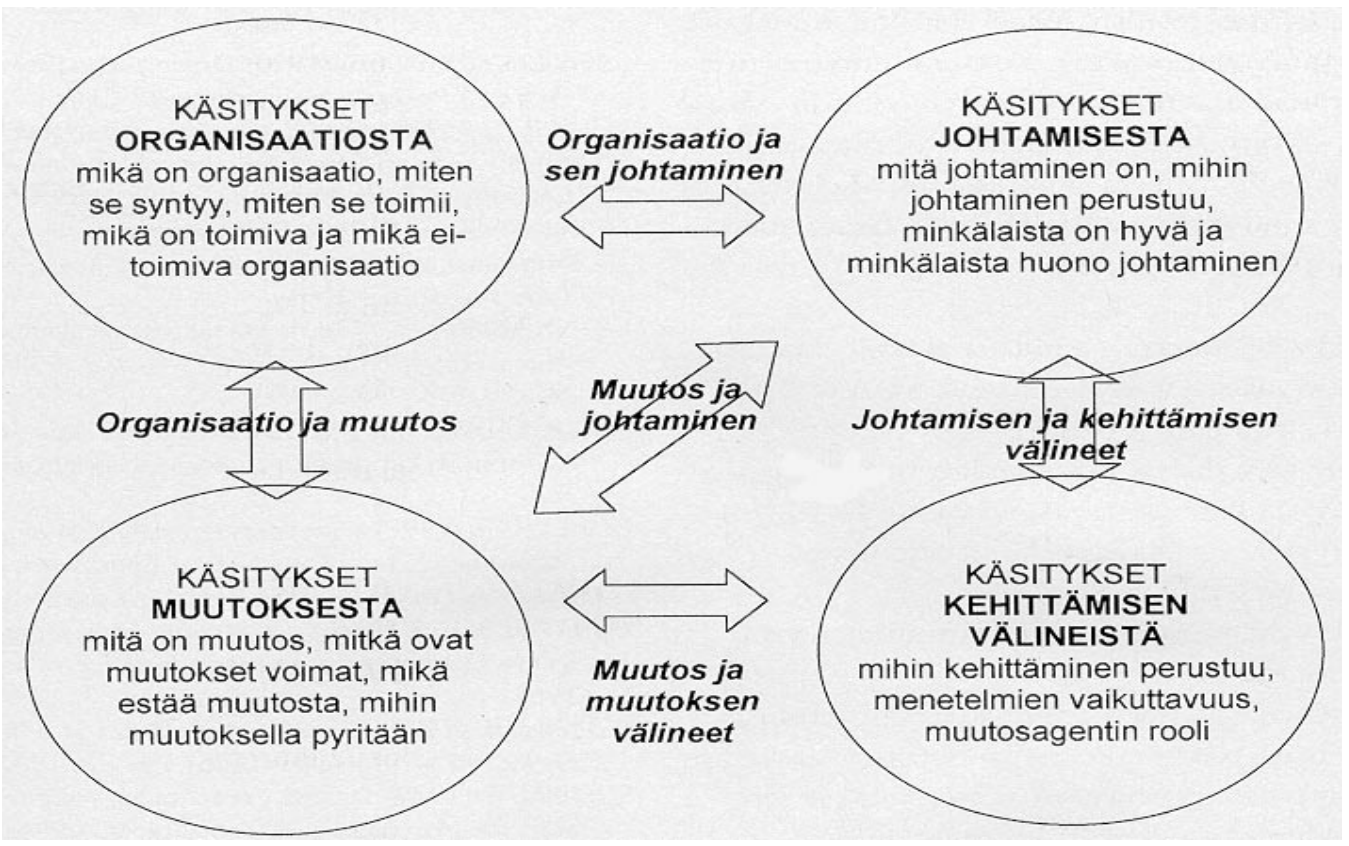

saation kehittämistoiminnan käyttöteorian eri elementtejä on pyritty kuvaan seuraavassa (kuva 5).

Sekä organisaation sisäisten että ulkoisten konsulttien ja -kehittäjien tai muutosagenttien ammatillisessa koulutuksessa ja valmentamisessa tulisi näiden käyttöteorioiden eri elementtien olla riittävän hyvin esillä. Itse asiassa kunkin kehittämistyötä tekevän velvollisuus olisi kyetä esittämään oma käyttöteoriansa, jos sellaista esimerkiksi asiakas vaatisi. Tämä ei ole helppoa. Yleensä kyetään esittämään erikseen kunkin neljän pääkategorian (organisaatio, johtaminen, muutos, välineet) malleja ja teorioita, mutta ei enää yhdistämään niihin liittyviä periaatteita toisiinsa (organisaatio ja sen johtaminen, organisaatio ja muutos, muutos ja johtaminen, johtamisen ja kehittämisen välineet, muutos ja muutoksen välineet).

$\mathrm{K}$ onsulttivalmennusten eri tarvitse tehdä kaikista organisaation kehittämisen asiantuntijoista generalisteja. Monet kehittämistehtävät tulevat edellyttämään jatkossakin erityisasiantuntemusta ja -osaamista. Mutta myös spesialistin on hyvä ymmärtää minkälaiseen kokonaisuuteen hänen työnsä liittyy ja miten se vaikuttaa organisaation muihin osiin. Hänen on myös yhä useam- min kyettävä osallistumaan moniammatillisten kehittämisryhmien toimintaan.

Vankan kokonaisnäkemyksen organisaation ja kehittämisen malleista tarvitsevat sellaiset kehittäjät

1 jotka toimivat lähellä organisaation ylintä johtoa,

1 joka toteuttavat laaja-alaisia muutoshankkeita, 1 joiden toiminnan vaikutus henkilöstöön tai yksittäisiin henkilöihinkin on suuri.

Tällaisia muutosagentteja ovat mm. kaikki henkilöstö- ja koulutussuunnittelusta organisaatiossa vastaavat. Vastaavasti työyhteisön kehittäjät, esim. ryhmädynaamista lähestymistapaa työryhmien kehittämiseen soveltavien konsulttien tulisi olla tietoisia oman toiminnan liittymisestä organisaation muuhun kokonaisuuteen. Toisaalta esimerkiksi rekrytointi- ja henkilöarviointikonsultointia harjoittavien konsulttien tulee tulevaisuudessa yhä selvemmin liittää toimintansa organisaation henkilöstö- ja osaamisstrategioihin.

Tonsulttivalmennukseen osallistuvat tulevat Uusein kursseilla joko hyvin tiedollisin tavoittein (halutaan ymmärtää organisaatioilmiöitä pa- 
remmin) tai korostuneen välineellisin tavoittein (haetaan konkreettisia menetelmiä tai tehokkaita "temppuja” tehdä työtä). Konsultointityöstä näistä kummastakaan tieto-taidosta ei ole paljoakaan apua, jos oma henkilökohtainen toiminta- ja roolimalli ei ole hallussa tai kirkastunut. Kehittämistyössä onnistumisessa ratkaisevan tärkeä merkitys on sellaisilla tekijöillä kuin

- 1 kyvyllä kommunikoida, viestittää, vaikuttaa

1 kyvyllä sietää epäjärjestystä, kaaosta ja ristiriitoja

1 kyvyllä analysoida, jäsentää, tulkita ja löytää kaaoksesta rakenteita

1 kyvyllä myös tilannekohtaisiin nopeisiin analyyseihin

1 kyvyllä joustaa ja muuttaa toimintamallia nopeasti

1 kyvyllä analysoida ihmisten toimintaa ja ohjata vuorovaikutustilanteita

1 kyvyllä tarkastella omaa toimintaa ja sen vaikutuksia, hyvällä itsetuntemuksella

1 pitkäjänteisyydellä, että saa tyydytystä pienistäkin edistysaskelista.

Konsulteille ja kehittäjille asetetaan yhä tiukempia vaatimuksia asiakasorganisaatioissa. Konsulttien valintaan ja toiminnan arviointiin liittyvää kirjallisuuttakin on yllättävästi noussut esiin (Lambert 1998, Fuller 1999). Siksi organisaatiokonsulttien ja kehittäjien valmennustarve on myös noussut esille. Perinteisesti konsulttivalmennus on liittynyt jonkin tietyn konsultointimallin tai -menetelmän esittelyyn ja harjoitteluun. Suomessa systemaattista, laaja-alaista tai "eklektista"- konsulttivalmennusta on aloitettu harjoittaa vasta 90luvulla ja siksi kokemuksetkin ovat vielä sangen hajanaisia.

\section{LÄHIEET}

FRENCH, W. \& Bell, C. (1990). Organization Development (4th ed.) Prentice Hall, Eglewood Cliffs

FULLER, G. (1999). Getting the Most Out of Your Consultant, a Guide to Selection through Implementation. CRC Press, Boca Raton.

HONKANEN, H. (1989). Organisaation ja työyhteisön kehittäminen, suuntauksia ja menetelmiä. Katsauksia 106. Työterveyslaitos, Helsinki.

HONKANEN, H. (1983). Henkilöstön hallinnoinnista voimavarojen kehittämiseen. Psykologia 1993/23, 361364.

JÄRVINEN, P. (1997). Prosessikonsultointi - mitä ja miten? Raportti 5. Tampereen aluetyöterveylaitos, Tampere.

LAMBERT, T. (1998). High Value Consulting, Managing and Maximising External and Internal Consultants for Massive Added Value. Nicholas Brealey, London.

MINTZBERG, H. (1983). Structure in Fives, Designing Effective Organizations. Prentice-Hall, Eglewood Cliffs 1983

SCHEIN, E. (1987). Organisaatiokulttuuri ja johtaminen. Ekonomia sarja. Weilin+Göös, Porvoo 1987(a)

SCHEIN, E. (1987) Process Consultation, volume II, Lessons for Managers and Consultants. Addison-Wesley, Reading 1987 (b).

SCHEIN, E. (1988). Process Consultation, volume I, Its Role in Organization Development (2nd ed). Addison-Wesley, Reading.

SPARROW, P. (1997). Organizational Competencies: Creating a Strategic Beahvioral Framework for Selection and Assessment. Teoksessa International Handbook for Selection and Assessment, ed. Anderson, N. \& Herriot P. John Wileys \& Sons, Chichester.

VARTIAINEN, M. (1994). Työn muutoksen työvälineet. Otatieto/Gaudeamus Tampere.

YUKL, G. (1994). Leadership in Organizations. Prentice Hall, Eglewood Cliffs.

Artikkeli saapui toimitukseen 3.2.1999. Se hyväksyttiin julkaistavaksi 15.2.1999.

\section{P O I M I N T O J A}

Johtamisen ja henkilöstön kehittämisen avuksi tuotettuja erilaisia työkaluja on markkinoilla runsaasti. Muutamia esimerkkejä:

TUJO = tulosjohtaminen, JOT = juuri oikeaan aikaan -järjestelmä, LEAN = uusi tuotantoprosessin ohjausjärjestelmä, verkostosolu = tuotantosolun uusi kehitysvaihe, $\mathrm{ABM}=$ active based management, $\mathrm{ocm}=$ order cycle management, vam $=$ value added management, $\mathrm{tcs}=$ total customer satisfaction, $\mathrm{bpq}=$ business process quality, $\mathrm{dbm}=$ databased marketing, abn = advanced business networking, YMS = ynnä muuta sellaista.

KIMmo KEVäTSALON väitöskirjasta Jäykät joustot ja tuhlatut resurssit. Vastapaino 1999. 